\title{
PENGEMBANGAN BAHAN AJAR MATA KULIAH FISIOLOGI REPRODUKSI DI JURUSAN BIOLOGI UNIVERSITAS NEGERI MALANG
}

\author{
Farizha Irmawati ${ }^{1,}$ Umie Lestari $^{2}$, Hadi Suwono ${ }^{3}$ \\ ${ }^{1}$ IKIP Budi Utomo, ${ }^{2,3}$ FMIPA Universitas Negeri Malang \\ Email: farizha99@gmail.com.
}

Diterima tanggal 7 Juli 2015 disetujui tanggal 17 Oktober 2015

\begin{abstract}
The purpose of the research and development is to produce teaching materials such as textbooks supporting course in Reproduction Physiology research based on the toxicity analysis for students who take a course in Reproduction Physiology. This research is a research and development, where the results of research become the teaching materials developed supporting Reproduction Physiology course. Development models have prepared using ADDIE Model. Sources of data in this research include laboratory research and validation of the results sheet of Biotechnology material experts, instructional design experts, the media, and the trials in students. The analysis is used quantitative and qualitative.The results of the research have developed become teaching materials like text books supporting courses and have been validated by the Reproduction Physiology, the Reproduction Physiology material experts, instructional design experts, the media, the individual testing, and group trials. Based on the results of the validation material have obtained value of $95 \%$, the results of the design validation and media experts to get the value of $93.75 \%$, it means that the teaching materials has been developed which suitable to be used as a teaching material support biotechnology course. While the experiments performed to get a data the percentage of students that are equal to $88,25 \%$ and included in the category of "very good", but still need to be revised based on advices and comments from students.
\end{abstract}

Keywords: Development, Instructional Material, ADDIE

\section{PENDAHULUAN}

Pendidikan merupakan fokus utama pembangunan di negara berkembang seperti Indonesia. Semakin banyaknya masyarakat terdidik di Indonesia, maka memunculkan harapan kemampuan sumber daya manusia Indonesia dapat meningkat. Pendidikan dalam rangka mewujudkan masyarakat Indonesia yang baru, tentunya mengalami hambatan maupun tantangan berupa demokratisasi pendidikan, disentralisasi managemen pendidikan, dan kualitas pendidikan, serta tantangan global yaitu pendidikan yang kompetitif dan inovatif.

Lembaga yang berperan serta dalam perkembangan ilmu pendidikan adalah pendidikan tinggi. Pendidikan tinggi merupakan kelanjutan pendidikan menengah yang mencakup program diploma, program sarjana, program magister, program doktor dan program profesi, serta program spesialis. Perguruan tinggi menyiapkan peserta didik menjadi anggota masyarakat yang memiliki kemampuan akademis, atau professional yang dapat menerapakan, mengembangkan, atau menciptakan ilmu pengetahuan dan teknologi atau kesenian (Keputusan Menteri Pendidikan Nasional RI No 232/U/2000).

Wijayanto (2009), mengungkapkan bahwa pendidikan tinggi merupakan sekumpulan masyarakat akademis, yaitu masyarakat ilmu pengetahuan yang mempunyai otonomi ilmu pengetahuan berupa kebebasan akademis dalam setiap disiplin ilmu, sesuai dengan prinsip dan metode masing-masing. Oleh karena itu, pendidikan tinggi dituntut untuk menghasilkan produk bermutu yang sesuai dengan kebutuhan dan harapan (Nasution, 2012). Salah satu produk dari perguruan tinggi berupa bahan ajar, yang merupakan salah satu sumber belajar, yakni segala sesuatu yang memudahkan peserta didik 
memperoleh sejumlah informasi pengetahuan, pengalaman, dan keterampilan dalam proses belajar mengajar.

Lembaga yang berperan serta dalam perkembangan pendidikan tinggi salah satunya adalah Universitas Negeri Malang (UM), terdapat program studi (Prodi) Biologi yang merupakan salah satu program akademik, yang disediakan di Fakultas Matematika dan Ilmu Pengetahuan Alam (FMIPA), bertujuan untuk menghasilkan Sarjana Biologi yang prospektif untuk dunia sains, dan IPA (Katalog Biologi, 2012). Ada beberapa mata kuliah yang diselenggarakan di Program Studi Biologi, diantaranya adalah mata kuliah Fisiologi reproduksi. Fisiologi reproduksi merupakan salah satu matakuliah pilihan yang ditempuh oleh mahasiswa jurusan Biologi, khususnya bidang peminatan Zoologi di Universitas Negeri Malang.

Standar kompetensi pada matakuliah Fisiologi Reproduksi adalah mahasiswa mampu memahami konsep dan prinsip-prinsip Fisiologi Reproduksi hewan vertebrata khususnya mamalia. Kompetensi dasar yaitu kemapuan mahasiswa untuk memahami bahan alam yang mempengaruhi fertilitas. Salah satu indikator pembelajaran yang ingin dicapai adalah mahasiswa dapat melakukan uji standar terhadap bahan alam yang bersifat estrogenik.

Indikator pembelajaran tersebut dapat tercapai apabila pembelajaran dapat terlaksana dengan baik dengan ditunjang oleh ketersediaan bahan ajar. Berdasarkan hasil angket yang disebar, diperoleh informasi bahwa belum ada bahan ajar Fisiologi Reproduksi yang memaknai back to nature melalui pemanfaatan herbal sebagai sumber yang berkhasiat sebagai tanaman obat yang kemudian dikaitkan dengan potensinya pada sistem reproduksi. Sebesar $80 \%$ mahasiswa mengungkapkan, bahwa sumber bacaan yang dipergunakan oleh mahasiswa umumnya berupa bahan ajar yang mengkaji secara teoritis, misalnya tentang anatomi dan fungsi reproduksi, mekanisme hormonal, siklus reproduksi dan belum ada yang membahas aplikasinya dengan kehidupan sehari-hari yang dijumpai di alam. Selain itu, sebagai kendala adalah bahasa komunikasi tertulisnya dalam bentuk bahasa asing sehingga konsep dalam bahan ajar masih sulit dipahami oleh mahasiswa.

Hal ini sesuai dengan hasil wawancara dengan dosen pengampu matakuliah yang menyatakan bahwa sumber belajar Fisiologi Reproduksi masih bersifat umum dan dalam bentuk textbook, powerpoint, diktat atau jurnal. Berdasarkan hasil observasi juga diketahui bahwa belum ada buku ajar yang menjelaskan tentang pemanfaatan bahan alam yang bersifat fitoestrogen.

Adanya fenomena tersebut maka perlu ada suatu bahan ajar berbasis penelitian sebagai penunjang mata kuliah Fisiologi Reproduksi, dengan adanya bahan ajar yang memuat prosedur dan hasil penelitian diharapkan mahasiswa dapat memahami langkah-langkah, selain itu dapat digunakan oleh dosen untuk memperkaya bahan ajar pada mata kuliah Fisiologi Reproduksi.

Pemilihan model pengembangan yang digunakan pengembang adalah ADDIE ini didasarkan atas pemikiran bahwa model ini: 1)memberikan kesempatan untuk melakukan revisis (evaluasi) secara terus menerus dalam setiap tahap yang dilalui sehingga dapat menghasilkan sesuatu, bahan ajar yang lebih baik, 2) model ini sangat sederhana namun implementsinya sistematik (Muriati, 2013). Prosedur yang dilakukan sesuai dengan tujuan yang diharapkan pengembang yang meliputi menganalisis, mendesain, mengembangkan, mengimplementasi dan mengevaluasi. Pemilihan model ini didasari atas pertimbangan bahwa model ini dikembangkan secara sistematis dan berpijak pada landasan teoretis desain pembelajaran.

Berdasarkan pemaparan di atas, maka penulis mengembangkan bahan ajar matakuliah Fisiologi Reproduksi berbasis riset, yang di dalamnya memuat tentang 
prosedur dan hasil penelitian tentang analisis toksisitas fitoestrogen.

\section{METODE}

Prosedur penelitian pengembangan bahan ajar berupa buku teks penunjang matakuliah Bioteknologi dilakukan dengan mengacu pada model pengembangan Model ADDIE (Branch, 2009). Model ini disusun secara terprogram dengan urutan-urutan kegiatan yang sistematis dalam upaya pemecahan masalah belajar yang berkaitan dengan sumber belajar yang sesuai dengan kebutuhan dan karakteristik pebelajar.

Model ini terdiri atas lima langkah, yaitu: (1) analyze (analisis), (2) design (perancangan), (3) development (pengembangan), (4) implementasi (implementation), dan (5) evaluation (evaluasi), disajikan pada Gambar 1.

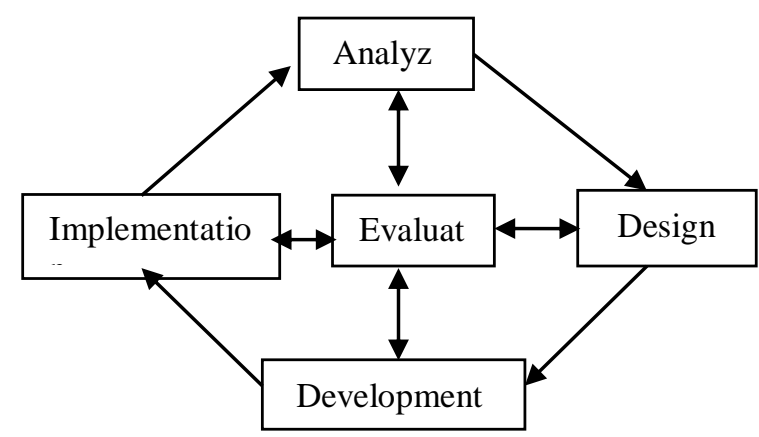

Gambar 1 Prosedur Pengembangan Model ADDIE (Branch, 2009)

\section{Analyze/Analisis}

Tahap analisis dilakuakan dengan mengidentifikasi dan mengembangkan pemahaman yang jelas tentang kebutuhan peserta didik mengenai bahan ajar Fisiologi Reproduksi. Hal ini disebut dengan tahap analisis kebutuhan, terdapat dua tahapan dalam analisis ini yaitu: a) analisisi kurikulum dan b) analisis sumber belajar. Analisis kurikulum dilakukan untuk mengetahui dan mengklarifikasi silabus yang dikembangan oleh kelompok bidang kajian mata kuliah Fisiologi Reproduksi, Jurusan Biologi Universitas Negeri Malang.
Berikut merupakan hasil analisis kurikulum yang telah dilakukan.

a. Standar Kompetensi:

Mahasiswa mampu memahami konsep dan prinsip-prinsip Fisiologi Reproduksi Hewan Vertebrata khususnya mamalia.

b. Kompetensi Dasar:

Kemampuan untuk memahami bahan alam yang mempengaruhi fertilitas.

c. Indikator Kompetensi:

1) Mahasiswa dapat menjelaskan macam bahan alam yang berpengaruh terhadap fertilitas

2) Mahasiswa dapat menjelaskan bahan alam yang bersifat estrogenik berpengaruh terhadap fertilitas.

3) Mahasiswa dapat melakukan uji standar terhadap bahan alam yang bersifat estrogenik

Tujuan dari analisis kebutuhan penelitian ini adalah untuk: a) mengidentifikasi bahan ajar Fisologi Reproduksi yang sudah ada, b) mengidentifikasi kelemahan dan kelebihan bahan ajar yang sudah ada, c) mengidentifikasi permasalahan yang dihadapi mahasiswa dalam memahami materi pada sumber belajar mata kuliah Fisiologi Reproduksi dan d) menentukan materi Fisiologi Reproduksi yang akan dijadikan sebagai buku ajar.

\section{Design /Desain}

Tahap perancangan (design) dilakukan perencanaan bahan ajar berupa bahan ajar tentang toksisitas fitoestrogen pada bahan alam, Selain itu, pada tahap ini juga dilakukan perancangan bahan ajar Fisiologi Reproduksi yang didasarkan dari teknikteknik dalam pelaksanaan penelitian, sampai pada hasil penelitian toksisitas fitoestrogen di laboratorium.

Desain bahan ajar yang akan disusun berdasarkan hasil penelitian tentang analisis toksisitas fitoestrogen bahan alam dijabarkan pada Tabel 1 . 
Tabel 1 Penjabaran Desain Bahan ajar

\begin{tabular}{l}
\hline Judul Buku Toksistas Fitoestrogen \\
\hline Kata Pengantar \\
Daftar Isi \\
Bab I Pendahuluan \\
Bab II Bahan Alam Mengandung Fitoestrogen \\
Bab III Fitoestrogen dalam $\quad$ Bengkuang \\
Bab IV Ginjal Tikus Betina Sprangue Dawley \\
Bab V Analisis Toksisitas \\
Glosarium \\
Daftar Pustaka \\
Tentang Penulis
\end{tabular}

\section{Development/ Pengembangan}

Tahap ini meliputi kegiatan membuat, mengembangkan memodifikasi dan uji coba bahan ajar yang dikembangkan pada matakuliah Fisiologi Reproduksi berdasarkan hasil penelitian analisis toksisitas fitoestrogen, di laboratorium. Tahapan pengembangan ini merupakan penjabaran dari tahapan desain, dan disusun berdasarkan hasil penelitian eksperimen analisis toksisitas fitoestrogen bahan alam, yang mencakup hasil serta teknik-teknik yang dilakukan dalam penelitian.

Uji coba produk bahan ajar Fisiologi Reproduksi oleh para ahli yang melibatkan satu orang ahli materi Fisiologi Reproduksi dan satu orang ahli media dan desain pembelajaran. Selanjutnya dilakukan evaluasi formatif hasil validasi berupa revisi dari ahli materi Fisiologi Reproduksi, dilanjutkan dengan evaluasi formatif hasil validasi berupa revisi dari ahli media dan desain pembelajaran. Sehingga dapat diketahui kekurangan dan kelebihannya, maka dilakukan perbaikan untuk mengurangi kelemahan tersebut.
Tabel 2 Kisi-kisi Instrumen Validasi Ahli Materi Pembelajaran

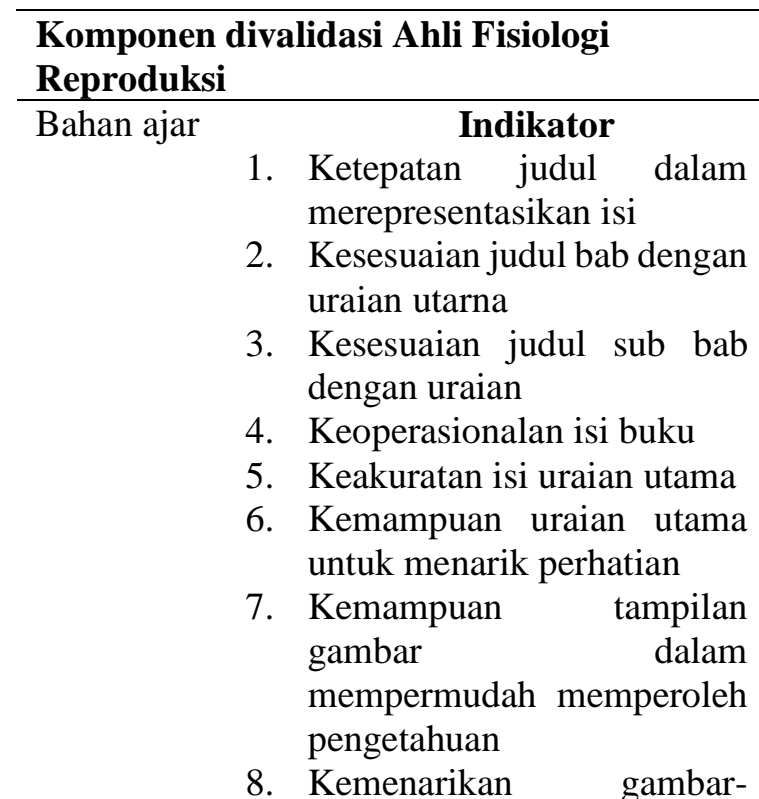
gambar sebagia pendukung isi buku

9. Ketetapan rujukan yang dipilih untuk menunjang bahasan pada uraian utama

10. Kemenarikan bahan ajar

Uji coba perorangan dan kelompok sedang dilakukan setelah mendapat validasi atau dinyatakan layak sebagai media pembelajaran Fisiologi Reproduksi. Uji coba ini dilakukan kepada mahasiswa yang sudah menempuh mata kuliah Fisiologi Reproduksi. Uji coba produk, dimaksudkan untuk mengumpulkan data yang dapat dipergunakan sebagai dasar untuk menentapkan tingkat keefisiensian atau daya tarik produk yang diinginkan.

Hasil uji coba digunakan dalam mengevaluasi bahan ajar Fisiologi Reproduksi berbasis riset untuk melihat tingkat efisiensi dari multimedia tersebut. Evaluasi pada tahapan pengembangan bahan ajar Fisiologi Reproduksi berbasis riset dilakukan berdasarkan kritikan, saran, serta masukan ahli validasi materi Fisisologi Reproduksi serta ahli media dan desain pembelajaran. Kisi-kisi komponen yang akan divalidasi disajikan pada Tabel 2 dan Tabel 3. 
Tabel 3 Kisi-kisi Instrumen Validasi Ahli Media \& Desain Pembelajaran.

\begin{tabular}{|c|c|}
\hline $\begin{array}{l}\text { Komponen } \\
\text { Pembelajarar }\end{array}$ & divalidasi Ahli Media \& Desain \\
\hline $\begin{array}{l}\text { Komponen } \\
\text { yang } \\
\text { divalidasi }\end{array}$ & $\begin{array}{l}\text { 1. Kemenarikan desain cover } \\
\text { 2. Kemenarikan desain bahan ajar } \\
\text { 3. Konsistensi judul tiap bab } \\
\text { 4. Kesesuaian judul dan sub judul } \\
\text { 5. Sistematika pengorganisasian } \\
\text { bahan ajar } \\
\text { 6. Kualitas tipografi bahan ajar } \\
\text { Bahan Ajar } \\
\text { 7. Ketepatan lay out, struktur dan } \\
\text { akses } \\
\text { 8. Konsistensi penomoran dalam } \\
\text { teks } \\
\text { 9. Kejelasan tampilan gambar } \\
\text { 10. Ketepatan sajian tabel } \\
\text { 11. Kejelasan Bahasa } \\
\text { 12. Kesesuaian penggunaan bahasa } \\
\text { dengan tingkat pemahaman } \\
\text { mahasiswa }\end{array}$ \\
\hline
\end{tabular}

Angket ini berisi kolom-kolom yang menunjukkan skor dari setiap komponen yang divalidasi. Kriteria penilaian bahan ajar dapat dilihat pada Tabel 4.

Tabel 4 Kriteria Penilaian Bahan Ajar

\begin{tabular}{cl}
\hline Skor & \multicolumn{1}{c}{ Indikator } \\
\hline 1 & Jika tidak baik/tidak sesuai \\
2 & Jika kurang baik/tidak sesuai \\
3 & Jika Baik/sesuai \\
4 & Jika sangat baik/sangat sesuai \\
\hline
\end{tabular}

\section{Implementation/ Implementasi}

Tahap implementasi tidak dilakukan pada pengembangan bahan ajar Fisiologi Reproduksi, karena keterbatasan waktu penelitian dan pengembangan, untuk melakukan penerapan bahan ajar berbasis penelitian tentang toksisitas fitoestrogen di dikelas. Direncanakan pada tahapan ini kegiatan pembelajaran, menggunakan model pembelajaran konstektual yang dipadu dengan inkuiri terbimbing yang memanfaatkan bahan ajar berbasis penelitian tentang toksisitas fitoestrogen

\section{Evaluation/Evaluasi}

Tahap terakhir adalah melakukan evaluasi (evaluation). Evaluasi adalah proses untuk melihat apakah bahan ajar yang dikembangkan berhasil, sesuai dengan harapan awal atau tidak. Sebenarnya tahap evaluasi terjadi pada setiap empat tahap di atas. Evaluasi yang terjadi pada setiap empat tahap di atas itu dinamakan evaluasi formatif karena tujuannya untuk kebutuhan revisi (Supriatna dan Mulyadi, 2009). Revisi produk dilakukan terhadap draft pengembangan produk yaitu berupa bahan ajar Fisiologi Reproduksi. Revisi didasarkan pada hasil validasi ahli materi dan ahli kegrafikan dengan mempertimbangkan media \& desain pembelajaran, setelah didapatkan hasil validasi selanjutnya dilakukan perbaikan dan penyempurnaan draft bahan ajar sehingga dihasilkan produk akhir yang memenuhi kriteria.

\section{Analisis Data}

Terdapat dua teknik analisis data yang digunakan untuk mengolah data dari hasil tinjauan para ahli, yaitu menggunakan analisis deskriptif kualitatif dan deskripsi kuantitatif.

\section{Analisis deskriptif kualitatif}

Analisis deskriptif kualitatif digunakan untuk mengolah data dari hasil review para ahli. Teknik analisis data ini digunakan dengan mengelompokkan informasi-informasi dari data hasil kualitatif yang berupa tanggapan dan saran perbaikan dari validasi ahli materi dan validasi ahli media dan desain pembelajaran. Analisis data dijadikan acuan untuk memperbaiki atau merevisi produk.

\section{Analisis deskriptif kuantitatif}

Untuk menganalisis skor yang terkumpul dari lembar validasi, maka digunakan statistik. Data dari lembar validasi dianalisis untuk mendapatkan gambaran tentang bahan ajar yang dikembangkan. Setelah lembar validasi terkumpul, kemudian dihitung persentase 
dari tiap-tiap butir pertanyaan pada lembar validasi tersebut dengan persamaan yang digunakan yaitu:

$$
\mathrm{P}=\frac{\sum(\text { keseluruhan jawaban angket })}{\mathrm{N} x \text { bobot tertinggi } x \text { jumlah responden }} \times 100 \%
$$

Keterangan:

$\mathrm{P} \quad=$ Persentase penilaian

$\mathrm{N}=$ Jumlah item angket

Tabel 5. Pengambilan Keputusan Revisi Buku

\begin{tabular}{|c|c|c|}
\hline $\begin{array}{l}\text { Tingkat } \\
\text { Pencapaian }\end{array}$ & Kualifikasi & Keterangan \\
\hline $81-100$ & Sangat baik & Tidak perlu revisi \\
\hline $61-80$ & Baik & Tidak perlu revisi \\
\hline $41-60$ & Cukup baik & Direvisi \\
\hline $21-40$ & Kurang baik & Direvisi \\
\hline $0-20$ & Sangat kurang baik & Direvisi \\
\hline
\end{tabular}

\section{HASIL DAN PEMBAHASAN Identitas produk}

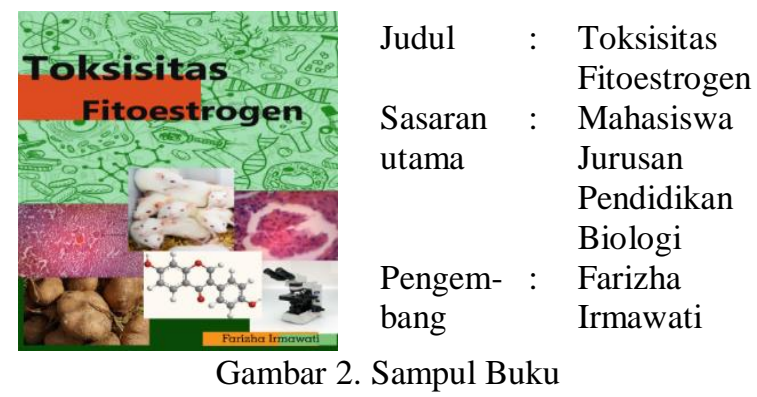

\section{Karakteristik}

a. Teks yang digunakan dalam bahan ajar ini adalah tipe Lucida Handwriting dan Maiandra GD dengan berbagai ukuran teks sesuai dengan kebutuhan.

b. Ukuran kertas yang digunakan dalam bahan ajar ini adalah B5.

c. Gambar dalam bahan ajar ini dikumpulkan dari berbagai foto kegiatan penelitian dan dari jurnal dan bahan ajar berbentuk buku teks sebagai penunjang.

\section{Tinjauan Kurikulum}

Pengembangan bahan ajar ini disusun berdasarkan tinjauan kurikulum yang ada pada matakuliah Fisiologi Reproduksi di
Jurusan Biologi. Bahan ajar hanya pada satu indikator yaitu mahasiswa dapat melakukan uji standar terhadap bahan alam yang bersifat estrogenik.

\section{Tujuan Pembelajaran}

Tujuan pembelajaran yang diharapkan adalah mahasiswa mampu melakukan praktikum uji standar atau uji toksisitas pada bahan alam yang mengandung fitoestrogen, serta mahasiswa mampu memahami teknik-teknik dalam melakukan uji toksisitas.

\section{Isi Materi}

Materi yang terdapat didalam bahan ajar merupakan materi uji standar atau uji toksisitas pada bahan alam, meliputi pengertian, prinsip, teknik serta hasil penelitian.

Pengembangan bahan ajar berdasarkan hasil penelitian tentang analisis toksisitas fitoestrogen diharapkan mahasiswa mendapat pengetahuan baru tentang teknik-teknik yang dilakukan dalam analisis toksisitas. Pengetahuan yang disampaikan kepada mahasiswa harus sesuai dengan indikator kompetensi yang telah dirumuskan sehingga tujuan dari pembelajaran tercapai. Adapun indikator mahasiswa dapat melakukan uji standar terhadap bahan alam yang bersifat estrogenik. Pada bahan ajar yang disusun telah memuat indikator kompetensi sehingga tujuan dari pembelajaran tercapai.

Bahan ajar memiliki peranan yang strategis dalam memfasilitasi kelancaran dalam proses pembelajaran (Sujarwo, 2008). Buku teks merupakan salah satu bahan ajar yang diperuntukkan bagi mahasiswa sebagai bekal pengetahuan dasar, dan digunakan sebagai sarana belajar dalam lingkup perkuliahan. Dipandang dari proses pembelajaran, penggunaan bahan ajar mempunyai peran penting. Jika tujuan pembelajarannya adalah untuk menjadikan mahasiswa memiliki berbagai kompetensi, maka perancangan bahan ajar harus 
memasukkan sejumlah prinsip yang dapat meningkatkan kompetensi yang hendak dimiliki mahasiswa.

Kusdiyanti (2011) mengungkapkan bahwa, buku yang disusun dalam kaitan dengan kurikulum hendaknya memperhatikan tujuan tertentu yang hendak dicapai melalui pendidikan yang dilakukan dengan menggunakan buku pelajaran yang bersangkutan. Oleh karena itu, sebelum buku pelajaran itu dikembangkan, penyusun atau penulis harus terlebih dahulu memahami tujuan satuan pendidikan, tujuan pendididkan dan cakupan materi semester, kelas atau satuan pendidikan tertentu.

Pada proses dan hasil penelitian digunakan sebagai bahan ajar toksisitas fitoestrogen, yang dapat membantu mahasiswa dalam memahami, indikator mahasiswa dapat melakukan uji standar terhadap bahan alam yang bersifat estrogenik kompetensi indikator untuk memahami konsep fertilitas dan standart kompetensi mampu memahami konsep dan prinsip-prinsip Fisiologi Reproduksi Hewan vertebrata khususnya mamalia.

Bahan ajar toksisitas fitoestrogen yang berbasis riset pada mata kuliah Fisiologi Reproduksi telah layak digunakan, karena sudah divalidasi dengan persentase tingkat pencapaian sebesar $95 \%$ dari ahli isi materi Fisiologi reproduksi, 93,75\% dari ahli media dan desain pembelajaran dan $88,25 \%$ uji mahasiswa kelompok sedang. Bahan ajar toksisitas fitoestrogen yang berbasis riset dalam kategori sangan baik, namun tetap dilakukan revisi sesuai saran dari ahli materi, media dan desain pembelajaran dan mahasiswa untuk penyempurnaan bahan ajar berupa buku teks.

Berdasarkan peraturan Menteri Pendidikan Nasional RI nomor 2 Tahun 2008 menjelaskan bahwa buku teks harus layak untuk dijadikan bahan ajar dan juga terdapat kriteria mutu (standart) buku teks pelajaran diantaranya, 1) kelayakan isi/materi, 2) kelayakan penyajian, 3) kelayakan bahasa, 4) kelayakan grafisan. Kriteria-kriteria tersebut telah tercantum dalam komponen lembar validasi yang dinilai oleh validator.

Tabel 6 Isi Bahan Ajar yang telah disusun

\begin{tabular}{|c|c|}
\hline \multicolumn{2}{|c|}{ Isi Bahan Ajar Analisis Toksisitas Fitoestrogen } \\
\hline Bab I & Keanekaragaman \\
\hline Pendahuluan & $\begin{array}{l}\text { Indonesia yang merupakan } \\
\text { sumber dari senyawa-senyawa }\end{array}$ \\
\hline Bab II & organik. \\
\hline Bahan Alam & A. Bahan Alam \\
\hline $\begin{array}{l}\text { Mengandung } \\
\text { Fitoestrogen }\end{array}$ & $\begin{array}{l}\text { Mengandung Fitoestrogen } \\
\text { dan Khasiatnya. }\end{array}$ \\
\hline & B. Fitoestrogen \\
\hline $\mathrm{Bab}$ III & \\
\hline $\begin{array}{l}\text { Fitoestrogen } \\
\text { dalam }\end{array}$ & $\begin{array}{l}\text { A. Geografis dan Penyebaran } \\
\text { Bengkuang }\end{array}$ \\
\hline Bengkuang & B. Habitat \\
\hline & C. Morfologi Bengkuang \\
\hline & D. Kandungan Bengkuang \\
\hline & E. Uji HPLC Bengkuang \\
\hline Bab IV & Struktur dan fungsi ginjal \\
\hline Ginjal & \\
\hline Bab V Analisi: & A. Toksisitas \\
\hline Toksisitas & B. Analisis Toksisitas \\
\hline Fitoestrogen & Fitoestrogen \\
\hline & $\begin{array}{l}\text { Toksisitas Fitoestrogen } \\
\text { terhadap Ginjal }\end{array}$ \\
\hline
\end{tabular}

\section{SIMPULAN}

Bahan ajar toksisitas fitoestrogen yang berbasis riset pada mata kuliah Fisiologi Reproduksi telah layak digunakan berdasarkan persentase hasil validasi ahli. Bahan ajar toksisitas fitoestrogen tingkat pencapaian sebesar $95 \%$ dari ahli isi materi Fisiologi reproduksi, 93,75\% dari ahli media dan desain pembelajaran dan 88,25\% uji mahasiswa kelompok sedang. Bahan ajar toksisitas fitoestrogen yang berbasis riset dalam kategori sangat baik dan layak dengan keputusan uji tidak perlu revisi.

\section{UCAPAN TERIMA KASIH}

Penelitian ini tidak akan terselesaikan tanpa bantuan dari Dr. Umie Lestari, M.Si dan Hadi Suwono, M.Si selaku pembimbing. Dr. Abdul Ghofur M.Si dan 
Dr.Aje Toenlioe, M.Pd selaku validator. Serta teman-teman seangkatan 2014 yang banyak membantu terlaksananya Penelitian ini.

\section{DAFTAR PUSTAKA}

Branch, R.M. (2009). Instructional Design: The ADDIE Approach. Speingger Science Business Media, LLC .

Brew, A. (2007). Imperatives and challenges in integrating research and teaching: A case study. Carrick Institute for Learning and Teaching in Higher Education DisciplineBased Development Forum: Teaching/Research Nexus.

Depdiknas. (2008). Panduan Pengembangan Bahan Ajar. Dokumen Pendidikan Nasional

Katalog Jurusan Biologi, (2012). Fakultas Matematika dan Ilmu Pengetahuan Alam, Universitas Negeri Malang.

Keputusan Menteri Pendidikan Nasional Republik Indonesia Nomor 232/U/2000 tentang Pedoman Penyusunan Kurikulum Pendidikan Tinggi Dan Penilaiana Hasil Belajar
Mahasiswa. (online http://luk.staff.ugm.ac.id/atur/Kepm en232/U-2000 Penyusunan

Kurikulum Pdf), diakses 2 Nopember 2013.

Kusdiyanti, Heny. (2011). Pelatihan Pengembangan Bahan Ajar Kearsipan Berbasis Potensi Lokal dalam rangka Program pemberdayaan Siswa Binaan Labsosdik di SMK se-Malang. UM: LP3.

Muriati, ST, (2013). Pengembangan Bahan Ajar Bio Sel dengan model ADDIE pada program Studi Pendidikan Biologi uin AlAUDIN Makasar. Tesis tidak diterbitkan Malang: Pps UM.

Nasution, Zulkarnain.(2012). Membangun Pencitraan Perguruan Tinggi. Swara Pendidikan,4 (7):14-15.

Wijayanto, Serian. (2009). Pengelolaan Perguruan Tinggi Secara Efisien, Efektif, dan Ekonomis untuk meningkatkan Mutu Penyelenggaraan dan Mutu Lulusan. Jakarta: Salemba Empat. 